\title{
National Doctors' Day 2020: To Lessen the Mortality of COVID-19
}

'Doctors' Day', is celebrated in India on July $1^{\text {st }}$ every year, holds special significance for medical practitioners in India. Just like in Mothers' Day we pay tribute to our Mothers, Fathers' Day to our Fathers, Teachers' Day to our teachers, Children's' Day to children; it is on this day that Doctors' are celebrated for the irreplaceable roles that they play in our lives. From dentists to neurosurgeons, homeopaths to heart specialists, physicians to pediatricians, Doctors' Day is the time to pay tribute to the entire medical profession.

The National Doctors' Day is celebrated to recognize and appreciate the contributions health care professionals make to enhance the lives of individuals as well as communities. The date varies from country to country. In India, it honors Dr. Bidhan Chandra Roy, West Bengal's second chief minister and a legendary physician. Dr. Roy was born on July $1^{\text {st }}, 1882$ and passed away 80 years later on the same date. He was honored with Bharat Ratna, the highest civilian award in India, on February $4^{\text {th }}, 1961$.

This special day is an ideal opportunity to remind people of the critical role doctors' play in our lives. Being a doctor is not just a 'job'; it is a challenging commitment to service that requires high levels of skill and precision. To make a tough job even tougher, doctors also have to deal with the reality that even a small professional mistake could drastically affect a patient's life. Doctors' Day is the perfect time for patients to acknowledge the high-pressured job and appreciate their Doctors' ability to comfort and heal. The theme of Doctors' Day this year is to "lessen the mortality of COVID-19." This encompasses spreading awareness about asymptomatic hypoxia and early aggressive therapy. Webinars and virtual meets will be held across the country to mark this day.

This day has special significance this year. Amid the COVID-19 pandemic, doctors and physicians all around the world have been recognized for their selfless service and acts. Working continuous shifts and putting their own health in danger, this day gives a perfect opportunity to salute their work. The COVID-19 pandemic has caused much morbidity and mortality to patients but also health care providers especially physicians caring for COVID-19-infected patients. To mark this day in a better way we should also focus on the factors associated with higher chances of mortality and morbidity among doctors. Lack of personal protective equipment (PPE) and inadequate PPE were commonly cited as a cause of death especially in developing nations and Italy. ${ }^{1}$ During pandemics, hospitals should organize physician shifts with mandatory rest and efforts should be made to get the doctors connected with their colleagues for information and social support. The government should adopt certain policies that may help physicians care for their families, provide lodging closer to the hospital and legislate life insurance enhancements etc. Efforts by the administration to make the life of physicians and their family better will certainly lift the morale of doctors dealing with COVID-19 patients. ${ }^{2,3}$

If we did not recognize the importance of doctors before, we are certainly learning just how much they contribute to society, amid the coronavirus pandemic. While we are self-isolating, it is the doctors who are constantly fighting for the lives of people who have been infected with the deadly virus. With the number of infected people on the rise every day and hospitals teeming with hundreds of people, it has never been more important to appreciate the efforts that doctors make to ensure that we sufficiently recover from whatever may be ailing us and continue to remain healthy. ${ }^{4}$ Doctors are truly the greatest heroes, of not just the present but of all time.

\section{REFERENCES}

1. World Health Organization (WHO). COVID-19 significantly impacts health services for noncommunicable diseases. Online article. Available from: https://www.who.int/news-room/detail/o1-o6-

(C) Neha Vaid. This is an open access article distributed under the terms of the Creative Commons Attribution License CC-BY-NC 4.o, which permits unrestricted use, distribution and reproduction in any medium, provided the use is not commercial and the original author and source are cited. 
2020-covid-19-significantly-impacts-health-servicesfor-noncommunicable-diseases [Last Accessed on $15^{\text {th }}$ June 2020]

2. Pandey SK, Sharma V. July 1 is National Doctors' Day: How to regain the lost public trust in healthcare?. Indian J Ophthalmol 2018;66:1045-6. 3. Habibi N. Doctor-Patient Relationship; National
Doctor's Day Special Editorial. Int Healthcare Res J. 2018;2(4):76-7.

https://doi.org/10.26440/IHRJ/o2_04/178 4 4. Sharma V. National Doctors' Day: Are the God's Men Safe?. Int Healthc Res J. 2019;3(4):135-7. https://doi.org/10.26440/IHRJ/0304.07254
Cite this article as:

Vaid N. National Doctors' Day 2020: To Lessen the Mortality of COVID-19. Int Healthc Res J. 2020;4(4):73-74. https://doi.org/10.26440/IHRJ/0404.07156 